\title{
Fungi on white-nose infected bats (Myotis spp.) in Eastern Canada show no decline in diversity associated with Pseudogymnoascus destructans (Ascomycota: Pseudeurotiaceae)
}

\author{
Karen J. Vanderwolf ${ }^{1,2^{*}}$, David Malloch ${ }^{1}$, and Donald F. McAlpine ${ }^{1}$ \\ ${ }^{1}$ New Brunswick Museum, 277 Douglas Ave., Saint John, New Brunswick E2K1E5, Canada \\ ${ }^{2}$ Canadian Wildlife Federation
}

\begin{abstract}
The introduction of the fungal pathogen Pseudogymnoascus destructans (Pd) to North America has stimulated research on the poorly known mycology of caves. It is possible that the introduction of $P d$ reduces the diversity of fungi associated with bats hibernating in caves. To test this hypothesis we examined the fungal assemblages associated with hibernating bats (Myotis spp.) pre- and post- white-nose syndrome (WNS) infection in eastern Canada using culture-dependent methods. We found the mean number of fungal taxa isolated from bats/ hibernaculum was not significantly different between pre-infection (29.6 $\pm 6.1 S D)$ and postinfection with WNS $(32.4 \pm 4.3)$. Although the number of fungal taxa per bat was significantly higher on Myotis lucifugus vs. M. septentrionalis, evidence suggests that this is a reflection of environmental features of individual hibernacula, rather than any biological difference between bat species. The composition and number of the most common and widespread fungal taxa on hibernating Myotis spp. did not change with the introduction of $P d$ to hibernacula. We found no evidence to suggest that $P d$ interacts with other fungi on the external surface of bats in hibernacula, even among fungal species of the same genus. However, our data do suggest that environmental characteristics of individual caves can have a significant influence on the fungal assemblages cultured from hibernating bats at specific hibernacula. Following the mortality of thousands of WNS-infected Myotis spp. in one hibernacula, we found that those fungal taxa growing on dead bats were cultured with increased frequency from live bats. This suggests that fungal assemblages on live bats may be sensitive to sporadic introductions of new fungal substrates to hibernacula.
\end{abstract}

Keywords: $\quad$ white-nose syndrome; cave fungi; Pseudogymnoascus destructans; Myotis; bats Received 10 August 2015; Revised 24 November 2015; Accepted 24 November 2015

Citation: Vanderwolf K.J., Malloch D. and McAlpine D.F., 2016. Fungi on white-nose infected bats (Myotis spp.) in Eastern Canada show no decline in diversity associated with Pseudogymnoascus destructans (Ascomycota: Pseudeurotiaceae). International Journal of Speleology, 45 (1), 43-50. Tampa, FL (USA) ISSN 0392-6672 http://dx.doi.org/10.5038/1827-806X.45.1.1946

\section{INTRODUCTION}

The role of the microbiome in immunity and disease progression has only recently been recognized, and has mainly focused on bacteria (Cui et al., 2013; Huffnagle \& Noverr, 2013; Lauer \& Hernandez, 2015). Whitenose syndrome (WNS) is a fungal disease of hibernating bats that has rapidly spread through the eastern United States and Canada, killing > 6.7 million bats since it was first reported in 2006 in Albany, New York (U.S. Fish and Wildlife Service, 2012). The fungus that causes WNS, Pseudogymnoascus destructans $(P d)$, is also found in Europe, but for reasons that are unclear, does not cause significant mortality or morbidity of
European bats (Wibbelt et al., 2010; Lorch et al., 2011; Puechmaille et al., 2011). Hypotheses for this include behavioral or physiological adaptations in European bats, or environmental differences between Europe and North America (Wibbelt et al., 2010). European strains of $P d$ are lethal to North American bats, demonstrating that the presence of different strains of $P d$ does not explain the lack of bat mortality in Europe (Warnecke et al., 2012). Whether $P d$ interacts with fungi and bacteria naturally occurring on bats, or whether the microbiome on bats or in hibernacula differs between North America and Europe, is unknown. The few studies on mycobiota present on hibernating bats have shown the composition of fungal taxa is 
similar between Europe and North America, although sample sizes are generally small and differences in methodology make comparison difficult (Larcher et al., 2003; Voyron et al., 2011; Johnson et al., 2013; Vanderwolf et al., 2013a).

In the United States, Johnson et al. (2013) sampled both $P d$-positive and $P d$-negative bats and found that the fungal diversity on the former was much lower than on the latter. This led these authors to hypothesize that $P d$ was responsible for suppressing the normal fungal diversity present on hibernating bats. Here we address this hypothesis by drawing on relatively large datasets describing fungal diversity on pre- and postWNS Myotis spp. bats in eastern Canada.

\section{METHODS}

The principal source for our pre-WNS information concerning fungal diversity on bats is a 2010 dataset consisting of 117 fungal species isolated from the external surface of apparently healthy hibernating bats (Myotis lucifugus LeConte 1831 and M. septentrionalis Trouessart 1897) in eight caves and mines in New Brunswick, Canada (Vanderwolf et al., 2013a). No Pd was cultured in 2010 and visible signs of WNS (fungal growth on bats and behavioral changes of bats) were not seen in the province until March 2011. We replicated our 2010 study during the winter of 2012 in some of the same caves where bats showed obvious signs of WNS (i.e. visible growth of $P d$ on exposed skin), with $P d$ presence confirmed by histology and qPCR at the Canadian Wildlife Health Cooperative. To gain an understanding of inter-year variation in fungal assemblages on bats at specific sites, we resampled hibernacula in 2012 that were sampled in 2010 and where WNS presence remained unconfirmed (i.e. no visible evidence of WNS-infected bats in 2012). However, we acknowledge that lack of visible WNS does not necessarily equate with lack of $P d$ presence (Verant et al., 2014). In an effort to track the source of some of the fungal spores on live hibernating bats we also cultured fungi from bat carcasses remaining in one of our study sites (Berryton Cave) 12-24 months following initial WNS mortality and compared this to fungal assemblages on live bats.

Of the 8 New Brunswick hibernacula sampled in 2010, 5 were re-sampled in 2012. In one excluded hibernaculum the bat population had decreased to < 10 bats due to WNS infection, below our prescribed sample size, while in another bats had changed roosting positions so as to no longer be accessible to us. The 5 hibernacula sampled included 3 limestone caves (one with WNS-positive bats), one gypsum cave (with WNS-positive bats), and one long-abandoned manganese mine (with WNS-positive bats). Data on physical characteristics of study sites can be found in Vanderwolf et al. (2012). We followed the protocol of the United States Fish and Wildlife Service (2009) for minimizing the spread of WNS during all visits to caves.

\section{Field Sampling}

During February - March 2012, swabs ( $\mathrm{n}=202$ ) were taken from the skin and dorsal fur of live
Myotis lucifugus $(\mathrm{n}=34)$ and $M$. septentrionalis ( $\mathrm{n}=16 ; 10$ bats/cave, 50 bats total) with a sterile, dry, cotton-tipped applicator. 'Skin' includes the face, ears, patagium, and/or uropatagium, depending on which skin surfaces were accessible to us. Bats were swabbed while roosting and were not removed from the walls, which precluded determining sex. In $P d-$ positive hibernacula, only Myotis spp. with visible $P d$ growth were sampled. Methods were identical to Vanderwolf et al. (2013a). Swabs were cultured on either dextrose-peptone-yeast extract (DPYA) agar or Sabouraud-Dextrose (SAB) agar, both of which contained the antibiotics chlortetracycline (30 mg/liter) and streptomycin (30 mg/liter). Four swabs were taken per bat using all combinations of fur or skin on either SAB or DPYA. A new applicator was used for each swab. After swabbing, the applicator was immediately streaked across an agar surface in a petri plate. Diluting streaks were completed in the hibernaculum within $3 \mathrm{~h}$ of the initial streak, after which plates were sealed in situ with parafilm (Pechiney Plastic Packaging, Chicago, IL).

In 2012 three dead $M$. lucifugus heavily colonized with fungal hyphae were collected from Berryton Cave and samples of hyphae cultured on DPYA. In 2013 fungal hyphae were removed from a dead $M$. lucifugus in situ in Berryton Cave using sterile technique and placed on 2 DPYA plates.

\section{Laboratory Processing}

All plates were incubated, inverted in the dark at $7^{\circ} \mathrm{C}$, and monitored over 4 months. Pure cultures of each distinct colony were maintained on DPYA without oxgall and sodium propionate. Identifications were carried out by comparing the micro- and macromorphological characteristics of the microfungi to the taxonomic literature and compendia. We had access to reference collections of cultures from Myotis spp. collected in 2010 and identified previously using a mix of sequencing and morphological features (Vanderwolf et al., 2013a). Some isolates were sent to taxonomic specialists for confirmation of identification, usually through a combination of morphological and molecular genetic techniques. Identifications of $P d$ were confirmed by sequencing as part of another study (Khankhet et al., 2014). Permanent cultures are housed in the University of Alberta Microfungus Collection and Herbarium (UAMH 11721, 1172311725, 11732-11734, 11813, 11815-11817) and desiccant-dried samples are vouchered in the New Brunswick Museum (NBM\# F-04812-04823, 04840, 04844-04870, 04883-04915, 04942-04948).

\section{Statistical Analysis}

The number of fungal taxa per bat in 2012 was not normally distributed, even with transformation. Therefore a Kruskal-Wallis test was used to determine if the number of fungal taxa per bat differed between hibernacula in 2012. A Mann-Whitney test was used to determine if the number of fungal taxa per bat in 2012 differed between $M$. lucifugus and $M$. septentrionalis and $P d$-positive versus $P d$-negative Myotis spp. When comparing 2012 results to the 2010 study, only data from 
the 5 hibernacula sampled in both years were used. A Wilcoxon signed ranks test was used to determine if the number of fungal taxa per bat among the hibernacula in 2012 was significantly different from that in 2010 . The average number of fungal taxa isolated from each hibernaculum was normally distributed and therefore a paired t-test was used to compare 2012 data to 2010. Minitab Statistical Software (https://www.minitab.com/enus/) was used for all tests.

\section{RESULTS}

\section{Post-WNS Fungal Diversity}

Fungi were successfully cultured from all 50 bats sampled in 2012 and from 187 of 202 (92.6\%) swabs collected, producing a total of 885 isolates. Swabs that did not produce fungi generally produced unidentified bacteria and yeast, which were also present on some swabs with fungi. A mean of $8.2 \pm 4.3 \mathrm{SD}$ fungal taxa (range: 2-14) were isolated from each bat (Table 1). Berryton Cave was notable for its high mean number of fungal taxa per bat compared to other sites we examined. The number of fungal taxa per bat was significantly different among hibernacula (Table 1), both when including Berryton $\left(\mathrm{H}_{4.50}=20.82, \mathrm{P}<0.00\right)$ and excluding Berryton $\left(\mathrm{H}_{3.40}=8.66, \mathrm{P}=0.03\right)$. The number of fungal taxa per bat was also significantly higher on $M$. lucifugus vs. $M$. septentrionalis $\left(\mathrm{W}_{2.50}=1016.5, \mathrm{p}=0.008\right)$ with a mean of $9.3 \pm 4.1 \mathrm{SD}$ fungal taxa per $M$. lucifugus $(\mathrm{n}=34)$ and $6.0 \pm 4.0 \mathrm{SD}$ per $M$. septentrionalis $(\mathrm{n}=16)$.

Eighty fungal taxa in 56 genera were isolated in 2012 (Table 2). Thirty-seven (46.3\%) of the 80 identified taxa were found on a single bat only. The fungal taxa most commonly isolated were: Pseudogymnoascus pannorum sensu lato $(68.6 \%$ of bats), Pd (66.7\%), Mucor spp. (52.9\%), Mortierella spp. (49.0\%), Penicillium spp. (45.1\%), Leuconeurospora spp. (33.3\%), Oidiodendron truncatum (33.3\%), Cladosporium spp. (25.5\%), Humicola cf. UAMH $11595 \mathrm{sp} .(23.5 \%)$, and Cephalotrichum stemonitis (21.6\%) (Table 2). Some fungal taxa were isolated more frequently using DPYA than SAB, such as Arachniotus spp. (10 positive DPYA plates, 0 SAB), Chrysosporium spp. (18 DPYA, 4 SAB), and Microascus spp. (33 DPYA, 13 SAB), while Mortierella spp. were isolated more frequently on SAB (37 SAB, 1 DPYA). Excluding sterile cultures, 51 fungal taxa were isolated using SAB ( $\mathrm{n}=102$ plates), 59 using DPYA $(\mathrm{n}=100), 60$ from fur $(\mathrm{n}=102)$, and 59 from skin $(\mathrm{n}=100)$.

Table 1. Mean number of fungal taxa per bat \pm standard deviation in 2012 and 2010 at five hibernacula in New Brunswick, Canada. In each year $\mathrm{n}=10$ Myotis spp./hibernacula were sampled. All hibernacula were $P d$-negative in 2010, while all were $P d$-positive in 2012. Only Berryton Cave had a significantly different number of fungal taxa per bat between 2010 and $2012(P=0.006)$.

\begin{tabular}{|l|c|c|c|c|}
\cline { 2 - 5 } \multicolumn{1}{c|}{} & $\mathbf{2 0 1 0}$ & $\mathbf{2 0 1 2}$ & $\begin{array}{c}\text { \# of M. lucifugus } \\
\text { sampled 2012 }\end{array}$ & $\begin{array}{c}\text { \# of M. septentrionalis } \\
\text { sampled 2012 }\end{array}$ \\
\hline Berryton Cave & $6.5 \pm 1.9$ & $13.1 \pm 2.6$ & 10 & 0 \\
\hline Harbell's Cave & $6.1 \pm 1.7$ & $4.7 \pm 3.9$ & 0 & 10 \\
\hline Howes Cave & $6.8 \pm 2.5$ & $7.0 \pm 3.0$ & 5 & 5 \\
\hline Markhamville Mine & $8.5 \pm 1.7$ & $9.1 \pm 3.6$ & 9 & 1 \\
\hline White Cave & $7.7 \pm 3.8$ & $7.4 \pm 3.8$ & 10 & 0 \\
\hline & & & & 16 \\
\hline Overall & $7.1 \pm 2.6$ & $8.2 \pm 4.3$ & 34 & \\
\hline
\end{tabular}

Table 2. Identification and frequency of fungal taxa isolated in 2012 from the skin and fur of hibernating bats $(L=M$. lucifugus, $\mathrm{n}=34 ; \mathrm{S}=M$. septentrionalis, $\mathrm{n}=16$ ) in 5 hibernacula in New Brunswick, Canada. Taxa marked with an asterisk $\left({ }^{*}\right)$ were not isolated in 2010.

\begin{tabular}{|c|c|c|}
\hline & $\begin{array}{c}\# \text { of } \\
\text { caves }\end{array}$ & \# of bats \\
\hline \multicolumn{3}{|l|}{ Ascomycota } \\
\hline Acremonium sp. & 2 & $1 \mathrm{~L}, 4 \mathrm{~S}$ \\
\hline A. berkeleyanum (P. Karst.) W. Gams & 1 & $1 \mathrm{~S}$ \\
\hline Arachniotus sp. & 2 & $2 \mathrm{~L}$ \\
\hline A. ruber (Tiegh.) J. Schröt. & 1 & $7 \mathrm{~L}$ \\
\hline *Arbusculina fragmentans Marvanová & 1 & $1 \mathrm{~S}$ \\
\hline Arthroderma silverae Currah, S.P. Abbott \& Sigler & 2 & $10 \mathrm{~L}$ \\
\hline Arthrographis kalrae (R.P. Tewari \& Macph.) Sigler \& J.W. Carmich. & 1 & $1 \mathrm{~L}$ \\
\hline *Aureobasidium pullulans (De Bary) G. Arnaud ex Cif., Ribaldi \& Corte & 2 & $1 \mathrm{~L}, 3 \mathrm{~S}$ \\
\hline *Auxarthron cf. californiense G.F. Orr \& Kuehn & 1 & $1 \mathrm{~L}$ \\
\hline Beauveria sp. & 1 & $1 \mathrm{~L}$ \\
\hline B. bassiana (Bals.-Criv.) Vuill. & 3 & $3 \mathrm{~L}, 2 \mathrm{~S}$ \\
\hline B. cf. brongniartii (Sacc.) Petch & 1 & $1 \mathrm{~L}$ \\
\hline Cadophora sp. & 1 & $1 \mathrm{~L}$ \\
\hline${ }^{*}$ C. malorum (Kidd \& Beaumont) W. Gams & 1 & $1 \mathrm{~L}$ \\
\hline Cephalotrichum stemonitis (Pers.) Link & 3 & $11 \mathrm{~L}, 1 \mathrm{~S}$ \\
\hline Chrysosporium sp. & 5 & $10 \mathrm{~L}, 2 \mathrm{~S}$ \\
\hline C. merdarium (Link) J.W. Carmich. & 1 & $7 \mathrm{~L}$ \\
\hline
\end{tabular}




\begin{tabular}{|c|c|c|}
\hline *Cladorrhinum sp. & 2 & $2 \mathrm{~L}$ \\
\hline Cladosporium sp. & 5 & $8 \mathrm{~L}, 5 \mathrm{~S}$ \\
\hline *Clonostachys sp. & 1 & $1 \mathrm{~S}$ \\
\hline${ }^{*}$ C. rosea (Link) Schroers, Samuels, Seifert \& W. Gams & 1 & $1 \mathrm{~S}$ \\
\hline Fusarium sp. & 1 & $1 \mathrm{~S}$ \\
\hline Gymnoascus reesii Baran. & 2 & $2 \mathrm{~L}$ \\
\hline *Humicola sp. & 1 & $1 \mathrm{~L}$ \\
\hline Humicola cf. UAMH 11595 & 4 & $10 \mathrm{~L}, 2 \mathrm{~S}$ \\
\hline Isaria farinosa (Holmsk.) Fr. & 4 & $3 \mathrm{~L}, 2 \mathrm{~S}$ \\
\hline *Kickxella alabastrina Coem. & 2 & $2 \mathrm{~L}$ \\
\hline${ }^{*}$ Lecythophora sp. & 1 & $1 \mathrm{~S}$ \\
\hline Leuconeurospora polypaeciloides Malloch, Sigler and Hambleton & 3 & $9 \mathrm{~L}, 1 \mathrm{~S}$ \\
\hline Leuconeurospora capsici (J.F.H. Beyma) Malloch, Sigler \& Hambleton & 3 & $10 \mathrm{~L}$ \\
\hline *Malbranchea sp. & 1 & $2 \mathrm{~S}$ \\
\hline Mammaria sp. & 2 & $2 \mathrm{~L}$ \\
\hline Microascus sp. & 2 & $2 \mathrm{~L}$ \\
\hline Microascus caviariformis Malloch \& Hubart & 3 & $10 \mathrm{~L}, 2 \mathrm{~S}$ \\
\hline Microascus type 2 & 1 & $10 \mathrm{~L}$ \\
\hline${ }^{*}$ Monodictys sp. & 1 & $1 \mathrm{~L}$ \\
\hline *Myceliophthora sp. & 1 & $1 \mathrm{~S}$ \\
\hline Oidiodendron sp. & 3 & $2 \mathrm{~L}, 1 \mathrm{~S}$ \\
\hline Oidiodendron type 2 & 1 & $1 \mathrm{~L}$ \\
\hline O. myxotrichoides M. Calduch, Gené \& Guarro & 2 & $1 \mathrm{~L}, 1 \mathrm{~S}$ \\
\hline O. truncatum G.L. Barron & 5 & $14 \mathrm{~L}, 2 \mathrm{~S}$ \\
\hline Paecilomyces carneus (Duché \& R. Heim) A.H.S. Br. \& G. Sm. & 1 & $1 \mathrm{~S}$ \\
\hline P. inflatus (Burnside) J.W. Carmich. & 1 & $1 \mathrm{~L}$ \\
\hline Penicillium sp. & 5 & $17 \mathrm{~L}, 6 \mathrm{~S}$ \\
\hline P. commune Thom & 1 & $1 \mathrm{~L}$ \\
\hline P. decumbens Thom & 1 & $1 \mathrm{~L}$ \\
\hline P. miczynskii K.M. Zalessky & 1 & $1 \mathrm{~L}$ \\
\hline$P$. solitum Westling & 1 & $1 \mathrm{~L}$ \\
\hline P. thomii Maire & 2 & $1 \mathrm{~L}, 3 \mathrm{~S}$ \\
\hline P. vulpinum (Cooke \& Massee) Seifert $\&$ Samson & 1 & $1 \mathrm{~L}$ \\
\hline *Phaeoacremonium sp. & 1 & $1 \mathrm{~S}$ \\
\hline Phialophora sp. & 1 & $3 \mathrm{~S}$ \\
\hline *Polytolypa sp. & 1 & $1 \mathrm{~L}$ \\
\hline Preussia sp. & 1 & $1 \mathrm{~L}$ \\
\hline Pseudoarachniotus ruber (Tiegh.) G.F. Orr, G.R. Ghosh \& K. Roy & 2 & $2 \mathrm{~L}$ \\
\hline Pseudogymnoascus pannorum sensu lato (Link) Minnis \& D.L. Lindner & 5 & $32 \mathrm{~L}, 2 \mathrm{~S}$ \\
\hline${ }^{*} P$. destructans (Blehert \& Gargas) Minnis \& D.L. Lindner & 5 & $30 \mathrm{~L}, 3 \mathrm{~S}$ \\
\hline P. roseus Raillo & 3 & $3 \mathrm{~L}, 1 \mathrm{~S}$ \\
\hline${ }^{*} c f$. Rhinocladiella sp. & 1 & $1 \mathrm{~S}$ \\
\hline Simplicillium sp. & 1 & $1 \mathrm{~L}$ \\
\hline *Sporendonema sp. & 1 & $1 \mathrm{~S}$ \\
\hline *Stachylidium sp. & 1 & $1 \mathrm{~S}$ \\
\hline *Thamnidium elegans Link & 1 & $1 \mathrm{~L}$ \\
\hline Thelebolus crustaceus (Fuckel) Kimbr. & 4 & $2 \mathrm{~L}, 3 \mathrm{~S}$ \\
\hline Thysanophora penicillioides (Roum.) W.B. Kendr. & 2 & $2 \mathrm{~S}$ \\
\hline *Torula sp. & 1 & $1 \mathrm{~L}$ \\
\hline Trichoderma sp. & 5 & $6 \mathrm{~L}, 3 \mathrm{~S}$ \\
\hline Trichosporiella sp. & 3 & $5 \mathrm{~L}, 1 \mathrm{~S}$ \\
\hline Wardomyces humicola Hennebert \& G.L. Barron & 1 & $1 \mathrm{~L}$ \\
\hline W. inflatus (Marchal) Hennebert & 1 & $2 \mathrm{~L}$ \\
\hline \multicolumn{3}{|l|}{ Basidiomycota } \\
\hline Asterotremella sp. & 1 & $1 \mathrm{~L}$ \\
\hline Unidentified Basidiomycete & 3 & $3 \mathrm{~L}, 3 \mathrm{~S}$ \\
\hline Cystofilobasidium sp. & 1 & $1 \mathrm{~L}$ \\
\hline Trichosporon sp. & 2 & $2 \mathrm{~L}, 2 \mathrm{~S}$ \\
\hline T. dulcitum (Berkhout) Weijman & 4 & $3 \mathrm{~L}, 4 \mathrm{~S}$ \\
\hline${ }^{*} \mathrm{cf}$. Tubulicrinis sp. & 1 & $1 \mathrm{~S}$ \\
\hline
\end{tabular}




\begin{tabular}{|l|c|c|}
\hline Zygomycota & & \\
\hline Mortierella sp. & 5 & $21 \mathrm{~L}, 4 \mathrm{~S}$ \\
\hline M. verticillata Linnem. & 1 & $1 \mathrm{~L}$ \\
\hline Mucor sp. & 5 & $22 \mathrm{~L}, 5 \mathrm{~S}$ \\
\hline Oomycota & & \\
\hline${ }^{*}$ Pythium sp. & 2 & $1 \mathrm{~L}, 1 \mathrm{~S}$ \\
\hline unidentified yeast & 1 & $1 \mathrm{~L}$ \\
\hline Sterile & 5 & $8 \mathrm{~L}, 9 \mathrm{~S}$ \\
\hline
\end{tabular}

\section{Pre- vs. post- WNS Fungal Diversity}

The mean number of fungal taxa isolated per hibernaculum was not significantly different in 2012 $(32.4 \pm 4.3 \mathrm{SD})$ when compared to $2010(29.6 \pm 6.1$ $\left.\mathrm{SD} ; \mathrm{T}_{1.4}=0.66, \mathrm{P}=0.543\right)$. Neither was the mean number of fungal taxa per bat in 2012 significantly different from that recorded in 2010 among the five hibernacula re-examined (Table 1; Wilcoxon statistic $_{1.49}=677, \mathrm{P}=0.137$ ). However, the mean number of fungal taxa per bat in Berryton Cave was significantly higher in $2012(13.1 \pm 2.6$ SD) than $2010\left(6.5 \pm 1.9 \mathrm{SD}\right.$; Wilcoxon statistic $_{1.9}=55$, $\mathrm{P}=0.006)$. This increase in the number of fungal taxa per bat in Berryton Cave between 2010 and 2012 was not reflected evenly across all fungal taxa, but rather in the number of bats from which Microascus type 2, Microascus caviariformis, Chrysosporium sp., Chrysosporium merdarium, $P d$, Leuconeurospora capsici, Arachniotus sp., Arthroderma silverae, and $O$. truncatum were cultured.

\section{Pseudogymnoascus destructans}

$P d$ was cultured from $100 \%$ of bats with visible $P d$ growth ( $\mathrm{n}=30$ bats), and from $19.0 \%$ of bats without visible $P d$ growth $(\mathrm{n}=21$ bats). Bats with visible $P d$ growth comprised $1 M$. septentrionalis and $29 M$. lucifugus. Bats without visible $P d$ growth included $16 M$. septentrionalis ( 3 culturing positive for $P d$ ) and $5 \mathrm{M}$. lucifugus ( 1 culturing positive for $P d$ ). All Myotis spp. sampled without visible $P d$ growth were located in hibernacula considered $P d$-negative. $P d$ positive Myotis spp. had significantly higher numbers of fungal taxa per bat $(9.9 \pm 4.0 \mathrm{SD})$ than $P d$-negative Myotis spp. (6.9 $\left.\pm 4.0 \mathrm{SD} ; \mathrm{W}_{1.58}=698, \mathrm{P}=0.0089\right)$. Among bats with visible $P d$ growth, culturing $P d$ was marginally more successful from skin $(93.1 \%$ positive swabs, $\mathrm{n}=58$ swabs $)$ than fur $(80.0 \%, \mathrm{n}=60)$ and on DPYA $(89.7 \%, \mathrm{n}=58)$ than $\operatorname{SAB}(83.3 \%, \mathrm{n}=60)$. For bats without visible $P d$ growth, culturing $P d$ was marginally more successful from skin $(14.3 \%$ positive swabs, $\mathrm{n}=42$ swabs $)$ than fur $(11.9 \%, \mathrm{n}=42)$ and on DPYA $(14.3 \%, \mathrm{n}=42)$ than SAB $(11.9 \%, \mathrm{n}=42)$. $P d$ co-occurred with other Pseudogymnoascus spp.; 28 bats harbored both $P d$ and Pseudogymnoascus spp. while 6 bats cultured positive for $P d$ but with no other Pseudogymnoascus spp. Although two of our study sites were identified as $P d$-negative based on the lack of visible fungal growth on bats, culture data proved both to be $P d$-positive. In Howes Cave, $P d$ was cultured from 1 of $10 \mathrm{M}$. lucifugus sampled in February 2012, one month before visible $P d$ growth on bats was observed. In Harbell's Cave, $P d$ was cultured from 3 of $10 \mathrm{M}$. septentrionalis (clustered together) sampled thirteen months before visible $P d$ growth on bats was observed. $P d$ was not detected prior to the visible appearance of fungal growth at other sites, in part because no culturing was done in 2011.

\section{Fungi on dead bats}

In 2012 Mucor sp., Mortierella sp., P. pannorum sensu lato, $P d$, Arachniotus sp., Acremonium spp., and $C$. merdarium were cultured from dead $M$. lucifugus in Berryton Cave ( $\mathrm{n}=3$ bats; Fig. 1). The composition of fungi on dead bats changed as carcass decomposition progressed. Fast growing Zygomycetes such as Mucor spp. and Mortierella spp. were commonly seen on freshly dead bats in Berryton Cave (Fig. 1A). As carcasses decomposed fungi that grow more slowly, such as Trichoderma sp., Arachniotus sp., P. pannorum sensu lato, and Chrysosporium spp., became evident (Fig. 1B). Carcasses at an advanced stage of decomposition, consisting only of remnant fur and bone, were often covered with ascomata of $M$. caviariformis (Fig. 1C). In 2013, P. pannorum sensu lato, M. caviariformis, Fusarium sp., Trichosporon dulcitum, L. capsici, A. silverae, Pd, O. truncatum, Mucor sp., Mortierella sp., and C. stemonitis were cultured from a long-dead M. lucifugus in Berryton Cave. All fungi isolated from dead bats were also cultured in 2010 and 2012 from live bats, with the exception that no $P d$ was cultured in 2010. Most notably, those fungi contributing to the elevated diversity found on live bats in Berryton Cave in 2012 were also isolated from dead bats remaining after a 2011 WNS mortality event in this hibernaculum.

\section{DISCUSSION}

\section{Post-WNS Fungal Diversity}

The greater number of fungal taxa isolated from $M$. lucifugus versus $M$. septentrionalis in 2012 may reflect environmental features of individual hibernacula rather than a biological difference between the bat species. Ten of $34 \mathrm{M}$. lucifugus sampled were roosting in Berryton Cave, the hibernaculum with the highest number of fungal taxa per bat. Conversely, ten of the $16 \mathrm{M}$. septentrionalis sampled were roosting in a hibernaculum with near the lowest fungal diversity among all sites in both 2010 and 2012 (Harbell's Cave). Vanderwolf et al. (2013a) found that hibernacula with substantial flowing or standing water bodies ( $\mathrm{n}=3$ sites) had lower fungal diversity compared to those lacking such features ( $\mathrm{n}=5$ sites). Harbell's Cave was the only site with substantial water (flowing) sampled in 2012. There was no significant difference in the number of fungal taxa isolated 

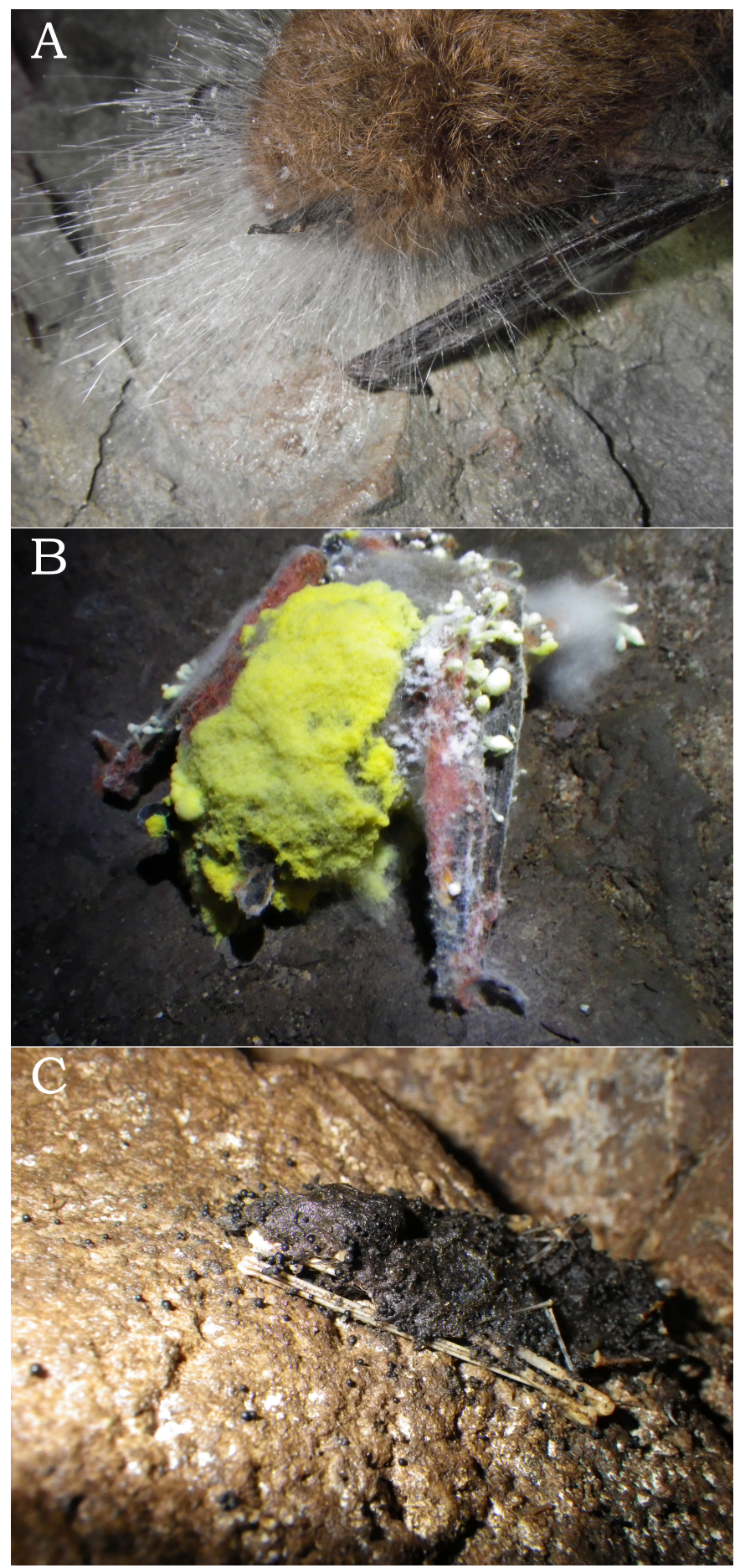

Fig. 1. All pictures taken in Berryton Cave. A) Mucor sp. growing from the head of a freshly dead Myotis sp. 15 March 2011 (carcass $<3$ months old); B) yellow Chrysosporium merdarium and red Arachniotus sp., among other species, growing on a dead Myotis sp. 14 December 2011 (carcass < 10 months old); C) Microascus caviariformis (ascomata shown) growing on a long dead Myotis sp. 14 December 2011 (carcass $\sim 12$ months old). Age of carcasses are rough estimates.

from M. lucifugus versus M. septentrionalis in 2010 (Vanderwolf et al., 2013a).

Berryton Cave had a significantly higher mean number of fungal taxa per bat than any other site sampled in 2012. Pre-WNS, Berryton Cave hosted the greatest number of hibernating bats among known hibernacula in New Brunswick (Vanderwolf et al., 2012). The arrival of WNS led to mass mortality of bats in this cave, with thousands of carcasses on the cave floor and walls. Although the majority of carcasses were removed by scavenging raccoons or for research purposes (McAlpine et al., 2011), we estimate $<100$ remained in the cave. During repeated visits over 3 years, we observed these carcasses being colonized by a succession of fungi. The fungal taxa that increased in frequency on live bats in Berryton Cave between 2010 and 2012 were identical to those cultured from dead bats. It appears that spores originating from carcasses settled on live bats, elevating over-all fungal diversity at this site. Few or no bat carcasses were found in other $P d$-positive hibernacula in the province. It appears $P d$-infected bats present at these sites exited hibernacula and died on the landscape. This varying pattern of mortality events at $P d$-infected bat hibernacula may therefore influence the diversity of fungi that can be cultured from live bats in the immediate aftermath of WNS infection.

Johnson et al. (2013) found a total of 31 fungal taxa on $M$. septentrionalis in two $P d$-negative hibernacula in Illinois, with a mean of $9.75 \pm 1.49 \mathrm{SD}$ fungal taxa per bat ( $\mathrm{n}=8$ bats) and $5.17 \pm 4.92 \mathrm{SD}$ ( $\mathrm{n}=6$ bats) respectively. They found 8 fungal taxa on $M$. sodalis ( $\mathrm{n}=1$ bat) in a $P d$-negative Illinois hibernaculum. Our results, both in $P d$-negative hibernacula in 2010 and $P d$-positive hibernacula in 2012, are very similar in terms of number and composition of fungal taxa (43 fungal taxa on $M$. septentrionalis in 2012 with $\mathrm{x}=6.0 \pm 4.0 \mathrm{SD}$ fungal taxa/bat, $\mathrm{n}=16 \mathrm{bats}$ ). Nineteen of 44 fungal taxa and 9 of the 10 most common taxa isolated from 3 bat species by Johnson et al. (2013) were also found on bats in New Brunswick in 2012 or 2010 (Vanderwolf et al. 2013a). Penicillium spp., Cladosporium spp., Pseudogymnoascus pannorum sensu lato, and Mortierella spp. are reported among the most common fungal taxa isolated from live bats in both New Brunswick and Illinois.

\section{Pre- vs. post- WNS Fungal Diversity}

In 2010, 83 fungal taxa in 57 genera ( $\mathrm{n}=50$ bats) were isolated (subset of data from Vanderwolf et al. 2013a) while 80 fungal taxa in 56 genera ( $\mathrm{n}=50$ bats) were isolated from the same hibernacula in 2012. In 2010, 24 genera were isolated that were not found in 2012 . In 2012, 25 genera were isolated that were not found in 2010. These unique genera were isolated from a mean of $1.5 \pm 1.0 \mathrm{SD}$ bats in 2010 (range 1-4) and $1.3 \pm 0.7$ SD bats in 2012 (range 1-4). These genera are either naturally rare in the cave environment or infrequently encountered by bats above ground. Excluding $P d, 9$ of the 10 fungal taxa most commonly isolated were identical in 2010 and 2012. The 30 most common taxa isolated in 2010 were also isolated in 2012. Clearly, the composition and number of the most common and widespread fungal taxa on hibernating Myotis spp. did not change with the introduction of $P d$ to New Brunswick hibernacula.

\section{Pseudogymnoascus destructans}

Johnson et al. (2013) found that $P d$-negative bats ( $\mathrm{n}=25$ ) sampled April-May in Illinois had a much greater diversity of fungi than $P d$-positive bats $(\mathrm{n}=5)$ sampled in June in Indiana. Although Johnson et al. (2013) suggested that it was presence of $P d$ that lead to this reduced fungal diversity, we believe 
the pattern they report is the result of unbalanced sample sizes, fungal assemblages sampled from bats during and outside the hibernation period, and the comparison of assemblages from different geographic regions. If the hypothesis that $P d$ is widespread and native to Europe is correct (Puechmaille et al., 2011), then the relatively larger numbers of studies on cave fungi carried out in Europe have been conducted in the presence of $P d$. These studies report diversities of fungal taxa similar to those reported for fungal studies from North American caves (Vanderwolf et al., 2013b). Our data suggest that environmental and ecological characteristics of individual caves are the principal variables influencing the fungal assemblages that can be cultured from hibernating bats at specific hibernacula.

We detected no difference in fungal diversity on the fur or skin of hibernating bats when comparing pre- (2010) and post- (2012) WNS data. However, Pdpositive bats had a significantly higher number of fungal taxa per bat than $P d$-negative bats sampled in 2012. As noted, we believe this difference was due to environmental conditions in individual hibernacula ( $P d$-positive Berryton and $P d$-negative Harbell's Cave). We found no evidence to suggest that in nature $P d$ interacts with other bat-associated fungi when present on the external surface of bats, even among closely related species of the same genus. As stated in Vanderwolf et al. (2013a), bats appear to acquire a diversity of spores from the environment and may be important fungal dispersers. However with the exception of Trichophyton reddelli (Lorch et al., 2015), $P d$, and an unidentified ascomycete recently reported on Eptesicus fuscus (McAlpine et al., 2016), fungi are not known to actively grow on bat skin or fur. This would seem to preclude competition between $P d$ and other fungi present on WNS-infected bats, although it would not preclude competition between fungal species on other substrates in the cave environment. Hoyt et al. (2015) found that a bacterium isolated from bats inhibits the growth of $P d$ in vitro. It is therefore possible that $P d$ may interact with other microbiota present on hibernating bats such as bacteria, viruses, or fungi that actively grow on bats that we did not culture. Regardless, the fungal assemblage found on cave walls and in cave sediments (Zhang et al., 2014) is similar to that on hibernating bats, demonstrating further that the ectomycota cultured from bats is a sub-sample of fungi present in the environment.

\section{Fungi on dead bats}

Previous studies of fungi that grow on dead bats have found many of the same or related taxa that we encountered in New Brunswick. Mucor sp. and Cladosporium sp. were identified from two dead Myotis sp. in Europe (Puechmaille et al., 2011). Penicillium sp. was found growing on two dead Rhinolophus ferrumequinum in the United Kingdom (Wibbelt et al., 2010), and Chrysosporium merdarium was isolated from a dead bat in Hungary (Zeller, 1966). In Italy, Mucor hiemalisf. hiemalis, $M$. racemosus, $M$. plumbeus, Mortierella polycephala, Mortierella gamsii, Fusarium dimerum, F. equiseti, Trichosporon chiropterorum,
Chrysosporium sp., C. merdarium, Alternaria sp., Aspergillus sp., Candida palmioleophila, Thielavia sp., Lecanicillium lecanii, Penicillium sp., Penicillium griseofulvum, and Cladosporium cladosporioides were isolated from 17 dead bats of various species (Voyron et al., 2011). Some of these fungi were also isolated from live bats in the same cave (Voyron et al., 2011). All fungi we isolated from dead bats in New Brunswick were also cultured from live bats, both in 2010 and 2012 (Vanderwolf et al., 2013a). Cave fungi appear to be opportunistic and proliferate when sources of nutrition become available in the oligotrophic cave habitat (Cubbon, 1976; Minn, 1988). In the absence of vertebrate and insect scavengers, fungi are important decomposers of organic matter in cave environments. Most fungi present in caves seem unable to use live bats as a food source. However, multiple fungal species proliferate on dead bats, with the spores these fungi produce dispersing into the surrounding cave environment. Where there is an influx of substrates into a cave on which fungi may grow (e.g. dead bats as a result of WNS mortality), the frequency of fungal taxa that can be cultured from live bats in hibernacula appears to shift. At one of our study sites in New Brunswick (Berryton Cave), we found that those fungal taxa growing on dead bats were cultured with increased frequency from live bats following the mortality of thousands of $P d$-infected Myotis spp..

\section{CONCLUSION}

The fungal assemblage cultured from hibernating bats was not affected by the presence of $P d$. Differences in fungal assemblages on $M$. lucifugus and $M$. septentrionalis appear to be related to environmental and ecological characteristics of individual caves. The increase in the number of fungal taxa per live bat in one hibernaculum from 2010 to 2012 is likely due to the growth of fungi on dead bats in the cave associated with WNS mortality. Currently lacking are detailed data on changes in fungal diversity over time as fungal substrates decompose in caves and how these changes might influence fungal assemblages in the surrounding environment. It appears that fungal assemblages on live bats may be sensitive to sporadic or rare introductions of fungal substrates to the cave environment.

\section{ACKNOWLEDGEMENTS}

Access to hibernacula located on private lands was generously provided by David Roberts, Joan Chown, and Tony Gilchrist. Greg Thorn helped with identification of Basidiomycetes. Sampling at Underground Lake Cave, a Class 1 New Brunswick Protected Natural Area, was made possible through a scientific research permit provided by the New Brunswick Department of Natural Resources Protected Natural Areas Program. Scientific permits for handling bats and/or entering sites was provided by the New Brunswick Department of Natural Resources Species-at-Risk Program and the New Brunswick Protected Natural Areas Program. Research funding was provided by the Canadian Wildlife Federation, Crabtree Foundation, New Brunswick 
Environmental Trust Fund, New Brunswick Wildlife Trust Fund, New Brunswick Department of Natural Resources, National Speleological Society WNS Rapid Response Fund, and Parks Canada.

\section{REFERENCES}

Cubbon B.D., 1976 - Cave flora. In: Ford T.D. \& Cullingford C.H.D. (Eds.), The science of speleology. London, England, Academic, p. 423-452.

Cui L., Morris A. \& Ghedin E., 2013 - The human mycobiome in health and disease. Genome Medicine, 5 (7): 63.

http://dx.doi.org/10.1186/gm467

Hoyt J.R., Cheng T.L., Langwig K.E., Hee M.M., Frick W.F. \& Kilpatrick A.M., 2015 - Bacteria isolated from bats inhibit the growth of Pseudogymnoascus destructans, the causative agent of White-Nose Syndrome. PLoS ONE, 10 (4): e0121329.

http://dx.doi.org/10.1371/journal.pone.0121329

Huffnagle G.B. \& Noverr M.C., 2013 - The emerging world of the fungal microbiome. Trends in Microbiology, 21 (7): 334-341.

http://dx.doi.org/10.1016/j.tim.2013.04.002

Johnson L.J.A.N., Miller A.N., McCleery R.A., McClanahan R., Kath J.A., Lueschow S. \& Porras-Alfaro A., 2013 - Psychrophilic and psychrotolerant fungi on bats and the presence of Geomyces spp. on bat wings prior to the arrival of White Nose Syndrome. Applied and Environmental Microbiology, 79 (18): 54-65. http://dx.doi.org/10.1128/AEM.01429-13

Khankhet J., Vanderwolf K.J., McAlpine D.F., McBurney S., Overy D.P., Slavic D. \& Xu J., 2014 - Clonal expansion of the Pseudogymnoascus destructans genotype in North America is accompanied by significant variation in phenotypic expression. PLoS ONE, 9 (8): e104684. http://dx.doi.org/10.1371/journal.pone.0104684

Larcher G., Bouchara J.P., Pailley P., Montfort D., Béguin H., de Bièvre C. \& Chabasse D., 2003 - Fungal biota associated with bats in western France. Journal de Mycologie Médical, 13: 29-34.

Lauer A., \& Hernandez T., 2015 - Cutaneous bacterial species from Lithobates catesbeianus can inhibit pathogenic dermatophytes. Mycopathologia, 179: 259268. http://dx.doi.org/10.1007/s11046-014-9838-1

Lorch J.M., Meteyer C.U., Behr M.J., Boyles J.G., Cryan P.M., Hicks A.C., Ballmann A.E., Coleman J.T.H., Redell D.N., Reeder D.M. \& Blehert D.S., 2011 - Experimental infection of bats with Geomyces destructans causes white-nose syndrome. Nature, 480: 376-378.

http://dx.doi.org/10.1038/nature10590

Lorch J.M., Minnis A.M., Meteyer C.U., Redell J.A., White J.P., Kaarakka H.M., Muller L.K., Lindner D.L., Verant M.L., Shearn-Bochsler V. \& Blehert D.S., 2015 - The fungus Trichophyton redellii $s p$. nov. causes skin infections that resemble white-nose syndrome of hibernating bats. Journal of Wildlife Diseases, 51 (1): 36-47. http://dx.doi.org/10.7589/2014-05-134

McAlpine D.F., Vanderwolf K.J., Forbes G.J. \& Malloch D., 2011 - Consumption of bats (Myotis sp.) by raccoons (Procyon lotor) during an outbreak of white-nose syndrome in New Brunswick: implications for bat mortality estimates. Canadian Field-Naturalist, 125: 157-160.

McAlpine D.F., McBurney S., Sabine M., Vanderwolf K.J., Park A. \& Cai H.Y., 2016 - Molecular detection of Pseudogymnoascus destructans (Ascomycota: Pseudeurotiaceae) and unidentified fungal dermatitides on big brown bats (Eptesicus fuscus) over-wintering in buildings. Journal of Wildlife Diseases, in press.
Minn K.H., 1988 - Fungus flora of Seongrya Cave in Korea. Transactions of the Mycological Society of Japan, 29: 479-487.

Puechmaille S.J., Wibbelt G., Korn V., Fuller H., Forget F., Muhldorfer K., Kurth A., Bogdanowicz W., Borel C., Bosch T., Cherezy T., Drebet M., Gorfol T., Haarsma A.J., Herhaus F., Hallart G., Hammer M., Jungmann C., Le Bris Y., Lutsar L., Masing M., Mulkens B., Passior K., Starrach M., Wojtaszewski A., Zophel U. \& Teeling E.C., 2011 - Pan-European distribution of white-nose syndrome fungus (Geomyces destructans) not associated with mass mortality. PLoS ONE, 6 (4): e19167. http://dx.doi.org/10.1371/journal.pone.0019167

United States Fish and Wildlife Service, 2009 Recommended procedures to prevent the possible spread of white-nose syndrome. Available online at:

http://whitenosesyndrome.org/topics/decontamination

U.S. Fish and Wildlife Service, 2012 - North American bat death toll exceeds 5.5 million from white-nose syndrome (Press release, 17 January). Retrieved from: http://static.whitenosesyndrome.org/sites/default/ files/files/wns_mortality_2012_nr_final_0.pdf

Vanderwolf K.J., McAlpine D.F., Forbes G.J. \& Malloch D., 2012 - Bat populations and cave microclimate prior to and at the outbreak of white-nose syndrome in New Brunswick. Canadian Field-Naturalist, 126: 125-134.

Vanderwolf K.J., McAlpine D.F., Malloch D. \& Forbes G.J., 2013a - Ectomycota associated with hibernating cave bats in eastern Canada prior to the emergence of white-nose syndrome. Northeastern Naturalist, 20 (1): 115-130.

http://dx.doi.org/10.1656/045.020.0109

Vanderwolf K.J., Malloch D., McAlpine D.F. \& Forbes G.J., $2013 \mathrm{~b}-\mathrm{A}$ world review of fungi, yeasts and slime molds in caves. International Journal of Speleology, 42 (1): 77-96. http://dx.doi.org/10.5038/1827-806X.42.1.9

Verant M.L., Meteyer C.U., Speakman J.R., Cryan P.M., Lorch J.M. \& Blehert D.S., 2014 - White-nose syndrome initiates a cascade of physiologic disturbances in the hibernating bat host. BMC Physiology, 14: 10. http://dx.doi.org/10.1186/s12899-014-0010-4

Voyron S., Lazzari A., Riccucci M., Calvini M. \& Varese G.C., 2011 - First mycological investigation on Italian bats. Hystrix, 22: 189-197. http://dx.doi.org/10.4404/Hystrix-22.1-4481

Warnecke L., Turner J.M., Bollinger T.K., Lorch J.M., Misra V., Cryan P.M., Wibbelt G., Blehert D.S. \& Willis C.K.R., 2012 - Inoculation of bats with European Geomyces destructans supports the novel pathogen hypothesis for the origin of white-nose syndrome. Proceedings of the National Academy of Sciences, USA, 109: 6999-7003.

http://dx.doi.org/10.1073/pnas.1200374109

Wibbelt G., Kurth A., Hellmann D., Weishaar M., Barlow A., Veith M., Pruger J., Gorfol T., Grosche L., Bontadina F., Zophel U., Seidl H.P., Cryan P.M. \& Blehert D.S., 2010 - White nose syndrome fungus (Geomyces destructans) in bats, Europe. Emerging Infectious Diseases, 16: 1237-1243. http://dx.doi.org/10.3201/eid1608.100002

Zeller L., 1966 - Keratinophilic fungi from the Baradla cave in Aggtelek (Biospeleologica Hungarica, XXII). Annals of the University of Sciences Budapest, Section Biology, 8: 375-388.

Zhang T., Victor T.R., Rajkumar S.S., Li X., Okoniewski J.C., Hicks A.C., Davis A.D., Broussard K., LaDeau S.L., Chaturvedi S. \& Chaturvedi V., $2014-$ Mycobiome of the bat White Nose Syndrome affected caves and mines reveals diversity of fungi and local adaptation by the fungal pathogen Pseudogymnoascus (Geomyces) destructans. PLoS ONE, 9 (9): e108714. http://dx.doi.org/10.1371/journal.pone.0108714 